\title{
Preliminary Validation of an Arabic Version of the Sport Motivation Scale (SMS-28)
}

\author{
Manal M. Bayyat ${ }^{1}$, Arabi H. Almoghrabi ${ }^{1} \&$ Khitam M. Ay ${ }^{2}$ \\ ${ }^{1}$ Department of Management and Coaching, Faculty of Physical Education, The University of Jordan, Jordan \\ ${ }^{2}$ Department of Supervision and Teaching, Faculty of Physical Education, The University of Jordan, Jordan \\ Correspondence: Manal Bayyat, Faculty of Physical Education, University of Jordan, Amman, Jordan. Tel: \\ 962-79-035-4435. E-mail: mabayyat@yahoo.com
}

Received: March 28, 2016 Accepted: April 25, 2016 Online Published: June 21, 2016

doi:10.5539/ass.v12n7p186 URL: http://dx.doi.org/10.5539/ass.v12n7p186

\begin{abstract}
This study aims to validate the Arabic version of the Sport Motivation Scale (SMS-28). SMS-28 is the English version of the French-Canadian scale l'Echelle de Motivation Dans Les Sport, which is based on the self-determination theory. The scale can reliably and validly measure the different forms of motivation toward sport. It consists of different subscales of intrinsic motivation (IM-to know, IM-to accomplish, IM-to experience), extrinsic motivation (identified regulation, introjected regulation, external regulation) and amotivation. The Arabic version of the scale was translated using the transcultural translation procedure. The final script of the translated scale was distributed to a sample of participants, which consists of a group of 208 students at the Faculty of Physical Education at the University of Jordan. The students were randomly selected and completed the scale voluntarily. Analytical analysis including factor analysis, Cronbach Alpha and Pearson correlation analysis were conducted. Results of the factor analysis reflected the validity of the scale, Cronbach Alpha showed adequate levels of internal consistency, while correlation values between the subscales were acceptable and reflected the motivation continuum suggested by the self-determination theory. Thus, an Arabic version of the sport motivation scale has emerged. Future studies using the Arabic version of the scale are encouraged.
\end{abstract}

Keywords: sport motivation scale, motivation, Arabic validation, self-determination theory, intrinsic motivation, extrinsic motivation

\section{Introduction}

Motivation can be defined as the direction and intensity of effort. The direction of effort refers to whether an individual seeks out, approaches, or is attracted to certain situations. The intensity of effort refers to how much effort a person puts forth in a particular situation (Weinberg \& Gould, 2011).

Motivation is a central and highly valued issue in the field of psychology. It plays an active role in sports. It has always been a concern to those who are involved in mobilizing others to act and achieve, such as managers, teachers, coaches and parents (Ryan \& Deci, 2000; Martens \& Webber, 2002). Motivation may arise when people value an activity and are personally committed to it. Motivation may also be driven by rewards or as a result of fear that one's actions are being monitored. Furthermore, it is imperative that coaches adopt a motivational climate avoiding verbally aggressive behaviors in order to increase their athletes' intrinsic motivation (Bekiari, Perkos, \& Gerodimos, 2015).

Self-Determination Theory (SDT) is a formal theory of motivation that uses an organismic dialectical approach. It begins with the assumption that people are active human beings, with high potentials toward growing, mastering ambient challenges, and integrating new experiences into a coherent sense of self. Natural developmental tendencies require social support. (SDT) defines intrinsic and varied extrinsic sources of motivation, and gives a description of the respective roles of intrinsic and types of extrinsic motivation in cognitive and social development. Individual differences are reflected on the individual's experience of autonomy, competence, and relatedness which are critical in education, arts, sport, and many other domains (Ryan \& Deci, 2000; Ryan, Williams, Patrick \& Deci, 2009).

SDT allows better understanding of human processes in different areas (education, work, leisure activities, parenting, etc.), in addition to guiding applications and interventions to improve human condition (Vallerand, 
Pelletier, \& Koestner, 2008).

According to SDT, there are many activities in which one can find intrinsic interests, yet a person will gravitate towards certain activities and avoid others. Therefore, SDT argues that only activities that satisfy certain basic psychological needs will be experienced as interests and be intrinsically motivated (Ryan et al., 2009).

Cognitive Evaluation Theory (CET) is a sub-theory of the (SDT). It specifically addresses the effects of social contexts on intrinsic motivation, while Organismic Integration Theory (OIT) addresses the topic of extrinsic motivation in its various forms. According to the (OIT); subtypes of extrinsic motivation are seen as falling along a continuum of internalization. The more internalized the extrinsic motivation is, the more autonomous the person will be when performing an action (Ryan \& Deci, n. d.).

Deci and Ryan (1999) have discussed education in their motivational approach. Different types of motivation were related to important psychological consequences (e.g., learning, performance), in addition to the role the theory plays in identifying determinants intrinsic and extrinsic motivation. Thus, a motivation scale in education was found, which speculated that behavior can be intrinsically motivated, extrinsically motivated, or amotivated. This approach appeared relevant to the field of sports (Ryan \& Deci, n. d.; Vallerand, Blais, Brière, \& Pelletier, 1989; Vallerand et al., 2008).

In order to study the different relations between determinants, motivation, and consequences in the sport domain, it was necessary to have an instrument that can reliably and validly measure the different forms of motivation toward sport. Existing measures of intrinsic and/or extrinsic sport motivation present conceptual problems and do not assess all seven constructs proposed by the SDT theory. SDT characterizes a broad framework for the study of human motivation and personality. Research has applied SDT in many domains including sport and physical activity (Brière, Vallerand, Blais, \& Pelletier, 1995; Pelletier, Fortier, Vallerand, Tuson, Briere, \& Blais, 1995; Ryan \& Deci, 2000).

Briere et al. (1995) developed and validated the "l'Echelle de Motivation dans les Sports (EMS) "in French, a scale of motivation that measures the different forms of motivation outlined in Deci and Ryan's theory. Pelletier et al. (1995) translated the EMS into English then validated it, they named it "Sport Motivation Scale (SMS-28)". The scale is considered to be the most common scale to measure motivation proposed by SDT in the sport context (Candela, Zucchetti, \& Villosio, 2014; Ntoumanis, 2001). At a later date, the scale was translated into different languages such as: Greek (Doganis, 2000), Spanish (Núñez, Martín-Albo, Navarro \& González, 2006), German (Burtscher, Furtner, Sachse, \& Burtscher 2011), Brazilian Portuguese (Filho, Andrade, Miranda, Nunez, Martin-Albo, \& Ribas, 2010) and Italian (Candela et al., 2014), in addition to the previously mentioned English translation. All translations were measured for their validity and consistency. Afterwards, several studies using these translated versions were conducted.

The SMS-28 scale consists of seven subscales, each of which includes four items. The scale assesses the three different types of motivation: Intrinsic Motivation, Extrinsic Motivation and Amotivation;

Intrinsic motivation (IM) is reflected in the scale through three subscales:

IM - To Know: engaging in an activity for the pleasure and the satisfaction that one experiences while learning, exploring, or trying to understand something new.

IM - To Accomplish: engaging in an activity for the pleasure and satisfaction experienced when one attempts to accomplish or create something, such as trying to master certain difficult training techniques in order to experience personal satisfaction.

IM - To Experience: engaging in an activity in order to experience stimulating sensations (e.g., sensory pleasure, aesthetic experiences, as well as fun and excitement) derived from one's engagement in the activity (Weinberg \& Gould, 2011).

Extrinsic motivation (EM) is also reflected in the scale through three subscales:

Identification Regulation: to feel that involvement in sports contributes in part to one's growth and development as a person),

Introjection Regulation: to feel the pressure of needing to be in good shape for aesthetic reasons, and feel embarrassed or ashamed of not being in top form.

External Regulation: participating in sport in order to receive praise from one's coach or to be urged to do so by one's parents are actions motivated by external regulation. In this case, the sport is performed not for fun but to obtain rewards (e.g., praise) or to avoid negative consequences (e.g., criticisms from parents) (Deci \& Ryan, 1985; Ntoumanis, 2001). 
Amotivation: individuals who do not perceive contingencies between their actions and the outcomes of their actions. They experience feelings of incompetence and lack of control (Deci \& Ryan, 1985). They are neither intrinsically motivated nor extrinsically motivated. When athletes are in such a state, they no longer identify any good reasons for continuing to train. Eventually, they may even decide to stop practicing their sport.

According to the first version of the SMS-28 scale in French, and all the translated scales that followed, motivation was considered the incentive behind participating and engaging in an activity (Deci \& Ryan, 1985).

The SMS-28 scale answered the question of "Why do you practice your sport?" The answers to the question of the scale were rated on a seven point Likert type scale from (1) (Does not correspond at all) to (7) (corresponds exactly), with a mid point of (4) for (corresponds moderately).

In light of the importance of conducting research on sport motivation and given that no existing scale adequately assesses intrinsic motivation, extrinsic motivation, and amotivation toward sport in the Arabic language, there emerged a need for an instrument that is based on a valid theoretical conceptualization; that is, a scale to assess motivation from a sound theoretical perspective. The SMS-28 scale was chosen to fulfill the purpose of the study.

The purpose of this study was to: (i) to translate the SMS -28 scale into the Arabic language and (ii) to validate the translated Arabic version of the SMS -28.

\section{Method}

\subsection{Translation of the SMS Scale to Arabic}

The SMS scale was translated into the Arabic language using the transcultural translation procedure (Parallel back -translation procedure) used in similar studies (Burtscher et al., 2011; Candela et al., 2014; Filho et al., 2010; Núñez et al., 2006; Pelletier et al., 1995). The English version of the scale was translated to Arabic by a bilingual individual. Then the Arabic script was translated back into English by another bilingual individual without knowing the original scale. The previous procedure was repeated once again with the help of two different bilingual individuals. Afterwards the Arabic version was evaluated by a specialist in order to add his final input. Thus the final version of the Arabic SMS scale was ready to be distributed to the participants in the study and was validated later on (see Appendix1).

\subsection{Validation of the Arabic Version of the SMS -28}

\subsubsection{Participants}

The sample of the study was composed of a total of 208 students. It included approximately $20 \%$ of the total number of undergraduate students of the Faculty of Physical Education at the University of Jordan. The sample was chosen randomly.

\subsubsection{Procedure}

The Arabic version of the SMS-28 scale answered the question of "Why do you practice your sport?". The scale reflected three main motivation categories: intrinsic motivation (IM), extrinsic motivation (EM) and amotivation. The scale consisted of 28 Items structured in seven subscales: IM - to know, IM - to accomplish, IM - to experience, identified regulation (EM), introjected regulation (EM), External Regulation (EM) and Amotivation. The answers of the scale's question were rated on a seven point Likert type scale from (1) (Does not correspond at all) to (7) (corresponds exactly), with a mid point of (4) for (corresponds moderately).

IM - To know included items no. 2,4,23,27, which are respectively: ("For the pleasure of knowing more about the sport that I practice"; "For the pleasure of discovering new training techniques"; "For the pleasure of learning new training techniques that I never tried before"; "For the pleasure of discovering new performance strategies").

IM - To accomplish includes items 8,12,15,20: ("Because it is absolutely necessary to do sports if one wants to be in shape"; "For the pleasure of improving some of my weak points"; "For the satisfaction I get when perfecting my skills"; "For the pleasure of executing certain difficult moves") respectively.

IM - To experience includes items 1,13,18,25: ("For the pleasure of living exciting experiences"; "For the excitement I feel when I am really involved in the activity"; "For the intense emotions I feel doing a sport that I like"; "Because I like the feeling of being totally immersed in the activity".) respectively.

Identified regulation includes items 7,11,17,24: ("Because, in my opinion, it is one of the best ways to meet people"; "Because it is one of the best ways I have chosen to develop myself in other aspects"; "Because it is a good way to learn lots of things that can be useful in other areas of my life"; "Because it is one of the best ways to maintain good relationships with my friends") respectively. 
Introjected regulation includes items 9,14,21,26: ("Because it is absolutely necessary to do sports if one wants to be in shape"; "Because I must do sports to feel good about myself"; "Because I would feel bad if I was not taking time to do it"; "Because I must do sports regularly") respectively.

External regulation includes items 6,10,16,22: ("Because this would make the people I know think highly of me"; "For the prestige of being an athlete"; "Because people around me believe it is important to be in shape"; "To show others how good I am at my sport") respectively.

Amotivation includes items 3,5,19,28: ("I used to have good reasons for doing sport, but now I am asking myself if I should continue doing it"; "I don't know anymore; I think I am incapable of succeeding in this sport"; "It is not clear to me anymore; I don't really think that I don't belong in the sport world"; "I often ask myself; do I seem capable of achieving the goals that I have set for myself?") respectively.

\subsection{Data Collection}

The Arabic version of the scale was distributed by the authors to the sample of the study. They were told that their contribution was totally voluntary and that it was for scientific research purposes. They were asked not to provide their names and were assured that all their information will remain strictly confidential. They were instructed to carefully read the items, check the answer that corresponded the most to them, and answer all items.

\subsection{Statistical Analysis}

The validation of the Arabic version included a principle component (an explanatory factor analysis) factor analysis with promax rotation for the seven subscales, a correlation matrix among the subscales and internal consistency for the subscales through internal analysis using Cronbach's coefficient alpha (Cronbach, 1951). Then, the data was analyzed using SPSS 14 for windows.

\section{Results}

\subsection{Skewness and Kurtosis}

An initial analysis for examining normal distribution of the Arabic version of SMS-28 scale values was conducted. Table (1) shows the results of means, standard deviations, skewness and kurtosis for the motivation subscales. Skewness values between +2 and -2 are considered acceptable in order to prove normal distribution. (Elliott, Alan C., Woodward, Wayne A., c2007). Skewness values of our data ranged between 0.50 for the subscale amotivation and - 0.52 for the subscale IM- to accomplish showed in table (1). Kurtosis values ranged between 0.40 for the external regulations and -0.88 for IM - to know subscale. These values suggest closeness to the normal curve.

Table 1. Descriptive Indicators for the SMS - 28 scale

\begin{tabular}{ccccc}
\hline Motivation subscales & Mean & Std. Dev & Skewness & Kurtosis \\
\hline IM -To Know & 21.59 & 4.36 & -0.27 & -0.88 \\
IM - To Accomplish & 21.73 & 4.56 & -0.52 & -0.31 \\
IM -To Experience & 20.55 & 4.24 & 0.04 & -0.71 \\
Intrinsic Motivation & 63.86 & 11.61 & -0.20 & -0.71 \\
Identified Regulation & 19.50 & 4.29 & 0.06 & -0.33 \\
Introjected Regulation & 20.40 & 4.34 & -0.11 & -0.75 \\
External Regulation & 18.55 & 5.12 & -0.26 & 0.40 \\
Extrinsic Motivation & 58.46 & 10.39 & 0.15 & -0.36 \\
Amotivation & 10.91 & 4.70 & 0.50 & 0.00 \\
\hline
\end{tabular}

\subsection{Factor Analysis}

A factor analysis using the principal components method with promax rotation was conducted using the SPSS editor. Table (2) illustrates the rotated factor loadings, the item code, the proposed scale for the item to belong to, the communalities and the item loadings on the factors being extracted.

Communalities reflect the sum of variance shared by an item among the factors being extracted. Typically, a minimum value of 0.40 is acceptable (Kline, 1994). Clearly, the minimum communality value observed was 0.414 for item b2: "For the pleasure of knowing more about the sport that I practice". 
The rotated factor matrix, which reflects how the items are weighted for each factor expresses the standardized beta coefficients between the items and the factor. Possible values range from -1 to +1 (SAS., 2015). Factor loadings reveal the items' contribution to the meaning of each factor. High loadings provide meaning and interpretation of factors. Items loaded differently in several factors. A cutoff of 0.3 was chosen to accept the loading according to literature (Elliott et al., c2007).

Table 2. Communalities and factor loadings using principal components with "Promax rotation"

\begin{tabular}{|c|c|c|c|c|c|c|c|c|c|}
\hline \multirow{2}{*}{$\begin{array}{l}\text { Item } \\
\text { Code }\end{array}$} & \multirow[t]{2}{*}{ Proposed Scale } & \multirow[t]{2}{*}{ Communalities } & \multicolumn{7}{|c|}{ Factor Loadings } \\
\hline & & & F1-k & F2-e & F3-a & F4-id & F5-in & F6-ex & F7Am \\
\hline B1 & IM -To Experience & 0.518 & & 0.380 & & & & & \\
\hline B2 & IM -To Know & 0.414 & 0.535 & & & & & & \\
\hline B3 & Amotivation & 0.633 & & & & & & & 0.640 \\
\hline B4 & IM -To Know & 0.512 & & & 0.501 & & & & \\
\hline B5 & Amotivation & 0.563 & & & & & & & 0.723 \\
\hline B6 & External Regulation & 0.566 & & & & & & 0.615 & \\
\hline B7 & $\begin{array}{l}\text { Identified } \\
\text { Regulation }\end{array}$ & 0.642 & & & & 0.778 & & & \\
\hline B8 & IM - To Accomplish & 0.686 & & & 0.753 & & & & \\
\hline B9 & $\begin{array}{l}\text { Introjected } \\
\text { Regulation }\end{array}$ & 0.523 & & & & & 0.617 & & \\
\hline $\mathrm{B} 10$ & External Regulation & 0.588 & & & & & & 0.675 & \\
\hline B11 & $\begin{array}{l}\text { Identified } \\
\text { Regulation }\end{array}$ & 0.590 & & & & 0.415 & & & \\
\hline B12 & IM - To Accomplish & 0.511 & & & 0.308 & & & & \\
\hline B13 & IM -To Experience & 0.674 & & 0.808 & & & & & \\
\hline B14 & $\begin{array}{l}\text { Introjected } \\
\text { Regulation }\end{array}$ & 0.702 & & & & & 0.425 & & \\
\hline B15 & IM - To Accomplish & 0.548 & & & 0.600 & & & & \\
\hline B16 & External Regulation & 0.601 & & & & & & 0.759 & \\
\hline B17 & $\begin{array}{l}\text { Identified } \\
\text { regulation }\end{array}$ & 0.489 & 0.605 & & & & & & \\
\hline B18 & IM -To Experience & 0.617 & & 0.612 & & & & & \\
\hline B19 & Amotivation & 0.476 & & & & & & & 0.602 \\
\hline $\mathrm{B} 20$ & IM - To Accomplish & 0.660 & & 0.444 & 0.776 & & & & \\
\hline B21 & $\begin{array}{l}\text { Introjected } \\
\text { Regulation }\end{array}$ & 0.618 & & & & & 0.713 & & \\
\hline $\mathrm{B} 22$ & External Regulation & 0.743 & & & & & & 0.840 & \\
\hline B23 & IM - To Know & 0.634 & 0.611 & & & & & & \\
\hline B24 & $\begin{array}{l}\text { Identified } \\
\text { regulation }\end{array}$ & 0.677 & & & & 0.738 & & & \\
\hline $\mathrm{B} 25$ & IM - To Experience & 0.658 & & 0.323 & & & & & \\
\hline B26 & $\begin{array}{l}\text { Introjected } \\
\text { Regulation }\end{array}$ & 0.594 & 0.749 & & & & & & \\
\hline B27 & IM - To Know & 0.530 & 0.681 & & & & & & \\
\hline B28 & Amotivation & 0.562 & & & & & & & 0.683 \\
\hline
\end{tabular}

F1-k $=$ to know, F2-e $=$ to experience, F3-a $=$ to accomplish, F4-id $=$ identified regulation, F5-in $=$ introjected regulation, $\mathrm{F} 6-\mathrm{ex}=$ external regulation, $\mathrm{F} 7 \mathrm{Am}=$ amotivation. 
Eigenvalue (latent root) is one of the critical matters that should be considered in factor analysis. It expresses the loadings sums of a factor and helps to decide the number of factors that will be included in the scale. Kaiser suggested that any factor in order to be acceptable should have an Eigenvalue of 1.00 or greater (reference). Table (3) reflects; (1) the Eigenvalues of each factor extracted. According to the results, all seven factors being extracted were accepted. The least Eigenvalue obtained was 2.33 for factor no. 4 Identified Regulation. (2) The explained variance. The more the explained value is, the more the items reflect that factor. The results show that factor no.3 (IM - To Accomplish) satisfies the larger variance followed by the factor no.1 (IM -To Know) and so on to the last factor. Explained variance of all factors was 59.0\%. (3)The Kaiser - Meyer - Olkin (KMO) measures data fitting adequacy to factor analysis. This measure varies between 0 and 1 , and the values closer to 1 are considered the better (SAS., 2015). Our KMO test value was 0.858 . Thus, current data fitting to factor analysis in this study is considered to be adequate.

Table 3. Eigenvalue, Explained variance $\%$ and KMO test for the factors being extracted

\begin{tabular}{cccc}
\hline Factor no. & Eigenvalue & Explained variance $\%$ & KMO test \\
\hline 3 & 5.37 & 27.64 & \\
1 & 4.43 & 7.64 & \\
2 & 4.91 & 5.83 & 0.858 \\
6 & 3.12 & 5.47 & \\
7 & 2.66 & 4.35 & \\
5 & 2.91 & 4.14 & \\
4 & 2.33 & 3.93 & \\
\hline
\end{tabular}

Correlations between each two subscales of the Motivation scales are presented diagonally in table (4) below. Most of the correlations were between moderate $(0.30-0.69)$ and high $(0.70$ or greater). Correlations between the Intrinsic Motivation and its subscales were strong 0.88. Likewise, correlations between the Extrinsic Motivation and its subscales were also relatively high 0.78 . The correlations between Intrinsic and Extrinsic Motivation were found to be strong 0.73. The correlations between Amotivation and the other Motivation scales were negative and almost weak. - 0.34, - 0.21 were the correlations between Amotivation and Intrinsic and Extrinsic Motivation s respectively. All the probability values related to the correlation values were statistically significant at (0.05 and 0.01$)$ levels.

Table (4) also shows the internal consistency of each motivation subscale (on diagonal). It was assessed using cronbach alpha approach for internal consistency. For this type of internal consistency value of $(0.60)$ or greater is considered to be a good cutoff (Cronbach, 1951). Values revealed suggest a very good and acceptable internal consistency level. The highest value of internal consistency was 0.87 for the Intrinsic Motivation. The minimum value obtained was 0.61 for the Amotivation, a value of 0.57 for the Introjected Regulation is considered below the cutoff but the researchers will accept it because it is too close.

Table 4. Pearson correlations among the motivation scales (below diagonal) and internal consistency values Cronbach alpa (on diagonal)

\begin{tabular}{cccccccccc}
\hline Motivation scales & IM-To K & IM- To A & IM-To E & IM & Id-R & Intro-R & Ex-R & EM & Am \\
\hline IM -To Know & $(0.72)$ & & & & & & & & \\
IM - To Accomplish & 0.65 & $(0.73)$ & & & & & & & \\
IM -To Experience & 0.68 & 0.68 & $(0.65)$ & & & & & & \\
Intrinsic Motivation & 0.88 & 0.88 & 0.89 & $(0.87)$ & & & & & \\
Identified Regulation & 0.54 & 0.50 & 0.56 & 0.60 & $(0.64)$ & & & & \\
Introjected Regulation & 0.54 & 0.52 & 0.53 & 0.60 & 0.39 & $(0.57)$ & & & \\
External Regulation & 0.36 & 0.41 & 0.37 & 0.43 & 0.27 & 0.37 & $(0.75)$ & & \\
Extrinsic Motivation & 0.64 & 0.62 & 0.66 & 0.73 & 0.73 & 0.78 & 0.76 & $(0.78)$ & \\
Amotivation & -0.31 & -0.25 & -0.33 & -0.34 & -0.17 & -0.33 & -0.01 & -0.21 & $(0.61)$ \\
\hline
\end{tabular}

Correlation is significant at the 0.01 level (2-tailed). 
Correlation is significant at the 0.05 level (2-tailed).

Note: IM-To K =IM - to know, IM- To A = IM - to accomplish, IM- To E = IM - to experience,

$\mathrm{IM}=$ Intrinsic Motivation, Id- $\mathrm{R}=$ identified regulation, Intro- $\mathrm{R}=$ introjected regulation,

$\mathrm{Ex}-\mathrm{R}=$ external regulation, $\mathrm{EM}=$ extrinsic motivation, $\mathrm{Am}=$ amotivation

\section{Discussion}

The issue of whether people adopt a certain behavior because they are driven by their own interests and values, or do it for external reasons not coming from within, is a matter of significance in every culture and represents a basic dimension by which people make sense of their own and others' behavior (Ryan \& Deci, 2000).

The aim of the study was to translate and validate the Arabic version of the SMS -28 scale of motivation. Using the factor analysis has helped to reduce the large number of the scale's items to a more manageable number of factors. Seven factors emerged; these were the same number of the original scales' factors. Each of the 28 items loaded and satisfied several factors at the same time. The authors chose the items that fulfilled the factors in the same way of the original scale, taking into consideration the cutoff of 0.30 recommended by literature as mentioned above.

However, items no. 4, 17 and 26 had loaded differently than SMS 28. For example, item no. 4 "For the pleasure of discovering new training techniques." was supposed to load in factor no. $1 \mathrm{IM}$ - to know. Instead it loaded in factor no. $2 \mathrm{IM}$ - to accomplish. The authors' explanation is that the sample might have been confused when answering this question. The surveyed students might have regarded discovering new training technique as an accomplishment by itself rather than having the opportunity to learn new techniques.

Also item no. 17 "Because it is a good way to learn lots of things that can be useful in other areas of my life", was supposed to load in factor no. 4 identified regulation. Instead it loaded in factor no. $3 \mathrm{IM}$ - to experience. Again, the sample might have figured that they practice the sport because they learn lots of things and transfer their learning into life experiences, rather than considering learning as a good opportunity to experience stimulations. As a matter of fact, the item might be somehow confusing even from the point of view of the authors. The authors agree with the sample that this item might express both IM - to experience and Identified regulations (EM). Thus, the authors suggested moving both items no.4 and no. 17 to the factors where they belong in the original version.

As for the Item 26 "Because I must do sports regularly", it was supposed to load in factor no. 5 introjected regulation. Instead it loaded in factor no. 1 IM - to know. The authors believe that such loading does not make any sense and it is far from being related to the intrinsic motivation factor "to know". The reason might be that the sample misunderstood the phrase due to translation errors or that the phrase did not express any of their motivations. Thus, the authors suggested omitting item 26 from the Arabic version of the SMS-28 scale.

Although internal consistency (reliability) values of the subscales were relatively low compared to similar studies, they were still accepted. The higher value was for the Intrinsic Motivation subscales and the lower was for the external regulation. The authors attribute such low values to the sample size.

Correlation results have reflected a strong connection between the Intrinsic Motivation subscales 0.88 and moderate correlation values 0.76 in average in the Extrinsic Motivation subscales. The correlation values of the subscales have reflected the self- determination continuum suggested by Deci and Ryan in 1985. Correlation values started higher at the beginning of the continuum, then displayed lower to negative at the opposite end of the continuum -0.34 .

Overall, the present results are in agreement with those obtained from previous similar studies; the Greek (Doganis, 2000), Spanish (Núñez, Martín-Albo, Navarro \& González, 2006), German (Burtscher, Furtner, Sachse \& Burtscher 2011), Brazilian Portuguese (Filho, Andrade, Miranda, Nunez, Martin-Albo, \& Ribas, 2010) and Italian (Candela et al., 2014), and provide support for the validation of the Arabic version.

\section{Conclusions}

The purpose of this study was to translate and validate the Arabic version of the SMS-28 motivation scale. Results from the factor analysis supported the seven factor structure of the Arabic SMS -28 scale and provided support for the construct validity. While internal consistency had demonstrated acceptable values for all subscales, correlations among the subscales revealed a simplex pattern confirming the self-determination continuum and the construct validity of the scale. All in all, the Arabic version of the SMS-28 scale in it's final version (see Appendix 2) is an adequate adaptation of the English version. Yet further psychometric evaluations 
using this scale are recommended.

This preliminary study has provided strong evidence for the scale's internal validity. However, according to Riemer, Fink, \& Fitzgerald (2002) external validity (or generalizability) of the scale is somewhat limited because participants were college aged individuals. Future researches using a sample of non-college aged adult sport participants are advised.

The sample size in this study was comparable to those of similar studies: 115 participant in the German version (Burtscher et al., 2011), 228 participants in the Italian version (Candela et al., 2014). Future studies using larger samples are highly encouraged, such as the English, the Brazilian and the Spanish versions with 593, 419 and 758 respectively. Additional research via this Arabic version of the SMS-28 scale in the Arab world is encouraged. The scale has seven subscales of motivation which leads to more accurate results in different psychometric aspects. Studies of causes and effects are needed to better understand sport settings. The authors recommend conducting future studies to better understand the effect of gender comparisons, different performance levels from different sports, different age groups (Anagnostou \& Patsiaouras, 2011), as well as to study the different relations between life skills and motivation levels (Erdvic, Øverby, \& Haugen, 2014), and the effect of different methods of teaching on enhancing motivation (Barzouka, Sotiropoulos \& Kioumourtzoglou, M., 2015; Kaltsatou, Fotiadou, Tsimaras, Kokaridas \& Sidiropoulou, 2013; Pitsi, Digelidis, \& Athanasios, 2015).

\section{References}

Anagnostou, G., \& Patsiaouras, A. (2011). Motivation of 10-12 years old Cypriot Students toward Sports Participation. Journal of Physical Education and Sport ${ }^{\circledR}(J P E S), 11(4), 401-405$.

Barzouka, K., Sotiropoulos, K., \& Kioumourtzoglou, M. (2015). The effect of feedback through an expert model observation on performance and learning the pass skill in volleyball and motivation. Journal of Physical Education and Sport ${ }^{\circledR}(J P E S), 15$ (3), 407 - 416.

Bekiari, A., Perkos, S., \& Gerodimos, V. (2015). Verbal aggression in basketball: perceived coach use and athlete Intrinsic and extrinsic motivation. Journal of Physical Education and Sport ${ }^{\circledR}$ (JPES), 15 (q), 96 - 102.

Brière, N. M., Vallerand, R. J., Blais, M. R., \& Pelletier, L. G. (1995). Devéloppement et validation d'une mesure de motivation intrinsèque, extrinsèque et d'Amotivation en context sportif: l'Echelle de Motivation dans les Sports (EMS). Int J Sport Psychol, 26(4), 465-489.

Burtscher, J., Furtner, M., Sachse, P., \& Burtscher, M. (2011). Validation of a German version of the Sport Motivation Scale (SMS28) and motivation analysis in competitive mountain run-ners. Perceptual \& Motor Skills, 3(112), 807-820. http://dx.doi.org/10.2466/05.06.25.PMS.112.3.807-820

Candela, F., Zucchetti, G., \& Villosio, C. (2014). Preliminary validation of the Italian version of the original sport motivation scale. Journal of Human Sport and Exercise, 9(1), 136-147. http://dx.doi.org/10.4100/jhse. 2014.91.14

Cronbach, L. J. (1951). Coeffiecient alpha and the internal structure of tests. Psychometrika, 16, 297-334. http://dx.doi.org/10.1007/BF02310555

Deci, E. L., \& Ryan, R. M. (1985). Intrinsic motivation and self-determination in human behavior. New York: Plenum. http://dx.doi.org/10.1007/978-1-4899-2271-7

Deci, E. L., \& Ryan, R. M. (1999). The "what" and "why" of goal pursuits: Human needs and the self determination of behavior. Psychological Inquiry, 11, 227-268. http://dx.doi.org/10.1207/S15327965PLI11 04_01

Doganis, G. (2000). Development of a Greek version of the Sport Motivation Scale. Perceptual \& Motor Skills, 90, 505-512. http://dx.doi.org/10.2466/pms.2000.90.2.505

Elliott, A. C., \& Woodward, W. A. (2007). Statistical analysis quick reference guidebook: with SPSS examples. Thousand Oaks, California: Sage Publications.

Erdvic, I. B., Øverby, N. C., \& Haugen, T. (2014). Students' self-determined motivation in physical education and intention to be physically active after graduation: The role of perceived competence and identity. Journal of Physical Education and Sport ${ }^{\circledR}$ (JPES), 14 (2), 232 - 241.

Filho, M. B., Andrade, D., Miranda, R., Nunez, J. L, Martin-Albo, J., \& Ribas, P. R. (2010). Preliminary validation of a brazilian version of the sport motivation scale. Univ Psychol, 10(2), 557-566.

Frederick,C. M., \& Ryan, R. M. (1995). Self determination in sport: A review using cognitive evaluation theory. International journal of sport psychology, 5-23. 
Kaltsatou, A., Fotiadou, E., Tsimaras, V., Kokaridas, D., \& Sidiropoulou, M. (2013). The effect of a traditional dance training program on dancing skills, rhythm and orientation abilities and on intrinsic motivation of individuals with hearing loss. Journal of Physical Education and Sport ${ }^{\circledR}(J P E S), 13(3), 438$ - 446.

Kline, P. (1994). An easy guide to factor analysis. London; New York: Routledge.

Martens, M. P., \& Webber, S. N. (2002). Psychometric properties of the Sport Motivation Scale: An evaluation with college varsity athletes from the U.S. Journal of Sport and Exercise Psychology, 24, 254-270.

Ntoumanis, N. A. (2001). Self-determination approach to the understanding of motivation in physical domain. British Journal of Educational Psychology, 71, 225-242. http://dx.doi.org/10.1348/000709901158497

Núñez, J. L., Martín-Albo, J., Navarro, J. G., \& González, V. M. (2006). Preliminary validation of a Spanish version of the Sport Motivation Scale. Perceptual and Motor Skills, 102, 919-930. http://dx.doi.org/10.2466/pms.102.3.919-930

Pelletier, L. G., Fortier, M. S., Vallerand, R. J., Tuson, K. M., Briere, N. M., \& Blais, M. R. (1995). Toward a new measure of intrinsic motivation, extrinsic motivation, and Amotivation in sports: TheSports Motivation Scale (SMS). J Sport Exercise Psy, 17(1), 35-53.

Pitsi, A., Digelidis, N., \& Athanasios, P. (2015). The effects of reciprocal and self-check teaching styles in students' intrinsic- extrinsic motivation, enjoyment and autonomy in teaching traditional Greek dances. Journal of Physical Education and Sport ${ }^{\circledR}(J P E S), 15(2), 352$ - 361.

Riemer, H., Fink, J. S., \& Fitzgerald, M. (2002). External validity of the sport motivation scale. Avante, 8(2), 57-66.

Ryan, R. M., \& Deci, E. L. (2000). Self-determination theory and the facilitation of intrinsic motivation, social development, and well-being. American Psychologist, 55, 68-78. http://dx.doi.org/10.1037/0003-066X. 55.1.68

Ryan, R. M., \& Deci, E. L. (n. d.). Self determination theory. Retrieved December 12, 2015, from http://www.selfdeterminationtheory.org/theory/

Ryan, R. M., Williams, G. C., Patrick, H., \& Deci, E. L. (2009). Self determination theory and physical activity: the dynamics of motivation in development and wellness. Hellenic Journal of Psychology, 107-124.

SAS., I. t. (2015, December 11). Ats.ucla.edu/stat/spss/output/factor1.htm. Retrieved December 11, 2015, from www.ats.ucla.edu/stat/spss/output/factor1.htm

Vallerand, R. J., Blais, M. R., Brière, N. M., \& Pelletier, L. G. (1989). Construction et validation de 1'Échelle de Motivation en Éducation (EME). Canadian Journal of Behavioral Sciences, 21, 323-349. http://dx.doi.org/10.1037/h0079855

Vallerand, R. J., Pelletier, L. G., \& Koestner, R. (2008). Reflections on Self-Determination Theory. Canadian Psychology, 49(3), 257-262. http://dx.doi.org/10.1037/a0012804

Weinberg, R. S., \& Gould, D. (2011). Foundations of Sport and Exercise Psychology (5th ed.). United States: Human Kinetics. http://dx.doi.org/10.1080/1612197X.2011.567106

\section{Appendix 1}

مقياس دافعيه ممارسة النشاط الرياضي (SMS-28)

$$
\text { ما السبب الذي يدفعك لممارسة النشاط الرياضي؟ }
$$

$$
\text { ضع دائره حول الرقم الذي يعكس مدى تطابق المعيار مع سبب ممارستاك للنشاط الرياضي. }
$$

\begin{tabular}{|c|c|c|c|c|c|c|c|c|}
\hline ينطبق تماما & & & بأيندال & طقليا & & لا لابطبق & السبب & \\
\hline 7 & 6 & 5 & 4 & 3 & 2 & 1 & الخبرات الرياضيه الممتعه. & 1 \\
\hline
\end{tabular}

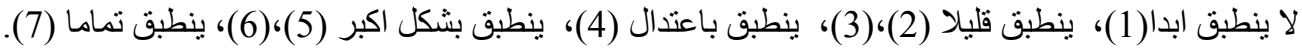




\begin{tabular}{|c|c|c|c|c|c|c|c|c|}
\hline 7 & 6 & 5 & 4 & 3 & 2 & 1 & السعاده التي اشعر بها حين اعرف اكثر عن الرياضه التي امارسها. & 2 \\
\hline 7 & 6 & 5 & 4 & 3 & 2 & 1 & في ان استمر او اتوقي الماضي الرغبه في ممارسة الرياضه ولكنني الان متردد & 3 \\
\hline 7 & 6 & 5 & 4 & 3 & 2 & 1 & اشعر بالسرور عندما اكتشف طرق تدريب جديده. & 4 \\
\hline 7 & 6 & 5 & 4 & 3 & 2 & 1 & قادر على التفوق في هذه الرياض مشتي بالنشاط الرياضي... اشعر انني غير & 5 \\
\hline 7 & 6 & 5 & 4 & 3 & 2 & 1 & اشعر باحتر ام الاشخاص من حولي. & 6 \\
\hline 7 & 6 & 5 & 4 & 3 & 2 & 1 & لان الرياضده، برأي، من افضل الطرق للتعرف على الناس. & 7 \\
\hline 7 & 6 & 5 & 4 & 3 & 2 & 1 & لانني اشعر بالرضا عند اتقان بعض المهار ات الفنيه الصعبه. & 8 \\
\hline 7 & 6 & 5 & 4 & 3 & 2 & 1 & اللانها لا بد من ممارسة النشاط الرياضي اذا اردت ان تحافظ على & 9 \\
\hline 7 & 6 & 5 & 4 & 3 & 2 & 1 & للمكانه الاجتماعيه التي يتميز بها الرياضي. & 10 \\
\hline 7 & 6 & 5 & 4 & 3 & 2 & 1 & لانها احدى افضل الطرق التي اخترتها لتطور جو انب شخصيتي & 11 \\
\hline 7 & 6 & 5 & 4 & 3 & 2 & 1 & للمتعه التي اشعر بها عندما احسن بعض حو انب الضعف لدي. & 12 \\
\hline 7 & 6 & 5 & 4 & 3 & 2 & 1 & للاثاره التي اشعر بها خلال ممارستي للنشاط الرياضي. & 13 \\
\hline 7 & 6 & 5 & 4 & 3 & 2 & 1 & لانني لا بد من ان امارس الرياضه كي اشعر بالسعاده. & 14 \\
\hline 7 & 6 & 5 & 4 & 3 & 2 & 1 & للرضـا الذي اشعر به عندما اصل بقدر اتي الى اعلى مستوى. & 15 \\
\hline 7 & 6 & 5 & 4 & 3 & 2 & 1 & لان الناس من حولي يرون انه لا بد ان احافظ على لياقتي. & 16 \\
\hline 7 & 6 & 5 & 4 & 3 & 2 & 1 & 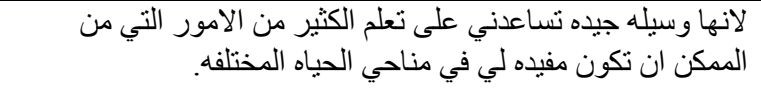 & 17 \\
\hline 7 & 6 & 5 & 4 & 3 & 2 & 1 & احب. بسب المشاعر القويه التي اشعر بها عندما امارس الرياضه التي & 18 \\
\hline 7 & 6 & 5 & 4 & 3 & 2 & 1 & لا اعرف حقا : انني اشعر اني لا اريد ان امارس الرياضه بعد الان. & 19 \\
\hline 7 & 6 & 5 & 4 & 3 & 2 & 1 & بسبب المتعه التي اشعر بها عندما انفذ بعض المهار ات الصعبه. & 20 \\
\hline 7 & 6 & 5 & 4 & 3 & 2 & 1 & لانني ساشعر بتأنيب الضمير ان لم امارس الرياضه. & 21 \\
\hline 7 & 6 & 5 & 4 & 3 & 2 & 1 & لاظهر للاخرين مدى بر اعتي في الرياضه التي امارسها. & 22 \\
\hline 7 & 6 & 5 & 4 & 3 & 2 & 1 & للمتعه التي اشعر بها عندما اتعلم مهار ات جديده لم اعرفها من قبل. & 23 \\
\hline 7 & 6 & 5 & 4 & 3 & 2 & 1 & لانها من افضل الطرق للحفاظ على العلاقات الاجتماعيه. & 24 \\
\hline 7 & 6 & 5 & 4 & 3 & 2 & 1 & لانني احب الشعور بالانغماس كلية في النشاط الرياضي. & 25 \\
\hline 7 & 6 & 5 & 4 & 3 & 2 & 1 & لانني مجبر على ممارسة الرياضه بشكل دائُ. & 26 \\
\hline 7 & 6 & 5 & 4 & 3 & 2 & 1 & للمتعة التي اشعر بها عندما اكتشف اسنر اتيجيات اداء جديده. & 27 \\
\hline 7 & 6 & 5 & 4 & 3 & 2 & 1 & مشاركتي في النشاط الريدو لي اني احقى الاهداف التي اسعى اليها من خلال & 28 \\
\hline
\end{tabular}

\section{Appendix 2}

مقياس دافعيه ممارسة النشاط الرياضي (SMS-28)

\section{ما السبب الذي يدفعك لممارسة النشاط الرياضي؟}

ضع دائره حول الرقم الذي يعكس مدى تطابق المعيار مع سبب ممارستك للنشاط الرياضي. لا ينطبق ابدا(1)، ينطبق قليلا (2)،(3)، ينطبق باعتدال (4)، ينطبق بثكل اكبر (5)،(6)، ينطبق تماما (7). 


\begin{tabular}{|c|c|c|c|c|c|c|c|c|}
\hline | ينطبق تماما & & بنشكزب & 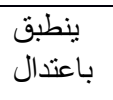 & 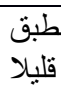 & & لا بنطبق & السبب & \\
\hline 7 & 6 & 5 & 4 & 3 & 2 & 1 & 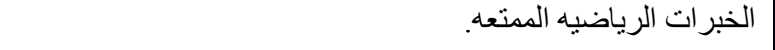 & 1 \\
\hline 7 & 6 & 5 & 4 & 3 & 2 & 1 & السعاده التي اشعر بها حين اعرف اكثر عن الرياضه التي امارسها. & 2 \\
\hline 7 & 6 & 5 & 4 & 3 & 2 & 1 & في ان استمر او انوقي. الرغبه في ممارسة الرياضها ولكنني الان متردد & 3 \\
\hline 7 & 6 & 5 & 4 & 3 & 2 & 1 & | اشعر بالسرور عندما اكتشف طرق تدريب جديده. & 4 \\
\hline 7 & 6 & 5 & 4 & 3 & 2 & 1 & قادر على التفوق في هذه الرياضي بالنشاط الرياضي... اشعر انني غير & 5 \\
\hline 7 & 6 & 5 & 4 & 3 & 2 & 1 & | اشعر باحترام الاشخاص من حولي. & 6 \\
\hline 7 & 6 & 5 & 4 & 3 & 2 & 1 & لان الرياضه،، برأي، من افضل الطرق للتعرف على الناس. & 7 \\
\hline 7 & 6 & 5 & 4 & 3 & 2 & 1 & لانني اشعر بالرضا عند اتقان بعض المهارات الفنيه الصعبه. & 8 \\
\hline 7 & 6 & 5 & 4 & 3 & 2 & 1 & اللانه لا بد من ممارسة النشاط الرياضي اذا اردت ان تحافظ على & 9 \\
\hline 7 & 6 & 5 & 4 & 3 & 2 & 1 & لللمكانه الاجتماعيه التي يتميز بها الرياضي. & 10 \\
\hline 7 & 6 & 5 & 4 & 3 & 2 & 1 & اللانها احدى افضل الطرق التي اخترتها لتطور جوانب شخصيتي & 11 \\
\hline 7 & 6 & 5 & 4 & 3 & 2 & 1 & لللمتعه التي اشعر بها عندما احسن بعض حوانب الضعف لدي. & 12 \\
\hline 7 & 6 & 5 & 4 & 3 & 2 & 1 & للاثاره التي اشعر بها خلال ممارستي للنشاط الرياضي. & 13 \\
\hline 7 & 6 & 5 & 4 & 3 & 2 & 1 & لانني لا بد من ان امارس الرياضه كي اشعر بالسعاده. & 14 \\
\hline 7 & 6 & 5 & 4 & 3 & 2 & 1 & للارضا الذي اشعر به عندما اصل بقدر اتي الى اعلى مستوى. & 15 \\
\hline 7 & 6 & 5 & 4 & 3 & 2 & 1 & لان الناس من حولي يرون انه لا بد ان احافظ على لياقتي. & 16 \\
\hline 7 & 6 & 5 & 4 & 3 & 2 & 1 & 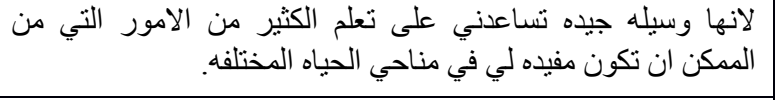 & 17 \\
\hline 7 & 6 & 5 & 4 & 3 & 2 & 1 & احب. بسبب المشاعر القويه التي اشعر بها عندما امارس الرياضه التي & 18 \\
\hline 7 & 6 & 5 & 4 & 3 & 2 & 1 & لا اعرف حقا : انني اشعر اني لا اريد ان امارس الرياضه بعد الان. & 19 \\
\hline 7 & 6 & 5 & 4 & 3 & 2 & 1 & بسبب المتعه التي انعر بها عندما انفذ بعض المهارات الصعبه. & 20 \\
\hline 7 & 6 & 5 & 4 & 3 & 2 & 1 & لانني سانشعر بتأنيب الضمير ان لم امارس الرياضها. & 21 \\
\hline 7 & 6 & 5 & 4 & 3 & 2 & 1 & لاظهر للاخرين مدى بر اعتي في الرياضه التي امارسها. & 22 \\
\hline 7 & 6 & 5 & 4 & 3 & 2 & 1 & لللمتعه التي اشعر بها عندما اتعلم مهار ات جديده لم اعرفها من قبل. & 23 \\
\hline 7 & 6 & 5 & 4 & 3 & 2 & 1 & لانها من افضل الطرق للحفاظ على العلاقات الاجتماعيه. & 24 \\
\hline 7 & 6 & 5 & 4 & 3 & 2 & 1 & لانني احب الشعور بالانغماس كلية في النشاط الرياضي. & 25 \\
\hline 7 & 6 & 5 & 4 & 3 & 2 & 1 & للمتعة التي اشعر بها عندما اكتثف استر اتيجيات اداء جديده. & 26 \\
\hline 7 & 6 & 5 & 4 & 3 & 2 & 1 & مشاركتي في النشاط الرياضي. لا احقق الاهداف التي اسعى اليها من خلال & 27 \\
\hline
\end{tabular}

\section{Copyrights}

Copyright for this article is retained by the author(s), with first publication rights granted to the journal.

This is an open-access article distributed under the terms and conditions of the Creative Commons Attribution license (http://creativecommons.org/licenses/by/3.0/) 